\title{
Promoting holistic learning for the development of competences in Mozambique
}

\author{
Jorge Jaime dos Santos Fringe*
}

doi: http://dx.doi.org/10.18543/tjhe-5(2)-2018pp19-43

Received: 22.01 .2018

Accepted: 02.05.2018

\begin{abstract}
This article presents results of a study carried out at the Faculty of Education of the University Eduardo Mondlane, in Mozambique, aimed to assess the extent to which the bachelor course in Psychology promotes multiple intelligences as superimposed to holistic learning styles within its effort to develop students' competences. For that purpose, 158 psychology students were invited to fill in a fourpoint Likert scale questionnaire. Respondents were asked to gauge lecturers' practices of employing different methods and strategies to promote multiple intelligences and holistic learning styles and to indicate what their preferences were concerning methods that could be employed more often. Results show that lecturers promote holistic learning, despite prominence of practices that are more tied to logical and analytical skills, in the left hemisphere, with less emphasis on right hemisphere processes such as ludic activities, drama and simulations, and physical involvement. Such results point to the need for the promotion of professional development efforts towards increased adoption of more holistic learning and multiple intelligences within the bachelor course in Psychology.
\end{abstract}

Keywords: competence-based education; constructivist learning; learning style flexibility; multiple intelligences; holistic learning styles; whole-brain model.

* Jorge Jaime dos Santos Fringe (jorge.fringe@gmail.com), PhD in Education, is lecturer at the Department of Psychology, Faculty of Education of the University Eduardo Mondlane, Mozambique.

More information about the author is available at the end of this article (after the bibliography list).

Acknowledgements: I would like to show my gratitude to the psychology students who have unconditionally made themselves available to fill in the questionnaire as well as to the Early Childhood Education students who have participated in the piloting of the same instrument. My deepest gratitude to Mirjam Van Lohuizen for her critical comments on this manuscript. I am as well grateful to Johanna van der Linden for her inputs. 


\section{Introduction}

Ongoing global transformations are pressurising Higher Education Institutions (HEI) to reconsider their practices. Among such transformations is the employers' plea for graduates who can continuously learn from practice through reflection, who care for quality, who are flexible, and who can work in teams. Mozambican higher education (HE) has been making reactive efforts such as aligning the courses to the labour market demand and the country's national needs ${ }^{1}$ in order to increase employability and relevance of HE. ${ }^{2}$ These statements confirm the concern with the provision of professionals who are both qualified and competent. ${ }^{3}$ We recall that a competent person is not necessarily qualified. A competent professional is able or capable to select and perform suitable behaviours to accomplish a certain goal. ${ }^{4}$ Whereas a qualified professional only represents a guarantee that he/she has reached a minimal requirement to perform certain job. ${ }^{5}$

The University Eduardo Mondlane (UEM) initiated a curriculum reform in 1999 aiming to align graduate profiles with country relevant competences. ${ }^{6}$ In 2001, the Faculty of Education (FACED) re-opened its doors adopting, for all its courses, the competence-based education (CBE). The rationale for such decision, on the one hand, was the need to offer courses that were oriented to professional practice since higher education was being challenged to bring together the university learning and world of work. On the other hand, there was the perceived fast and remarked change from a static work environment based on qualifications to a dynamic environment based in competences and focused on the individual. Therefore, knowledge acquisition was not anymore the main learning objective. Rather, the objective rested on

${ }^{1}$ Ministry of Higher Education, Science and Technology, Strategic Plan of Higher Education in Mozambique 200-2010 (Mozambique, 2000), 11.

${ }^{2}$ Ministério da Educação, Plano estratégico do Ensino Superior 2012-2020 (Mozambique, 2012), 17.

${ }^{3}$ Wim G Kouwenhoven, "Designing for Competence: Towards a Competence-Based Curriculum for the Faculty of Education of the Eduardo Mondlane University" (PhD diss., University of Twente, 2003), 221.

${ }^{4}$ Kouwenhoven, "Designing for Competence," 54.

5 Anna Serbati, "Implementation of Competence-Based Approach: Stories of Practices and the Tuning Contribution to Academic Innovation," Tuning Journal of Higher Education 3, no. 1 (2015): 26,10.18543/tjhe-3(1)-2015pp19-56.

${ }^{6}$ Johanna van der Linden and Mendonça Marta, "From Competence-Based Teaching to Competence-Based Learning: The Case of Generic Competencies in the Faculty of Education at the Eduardo Mondlane University in Mozambique," Perspectives in Education 24, no. 3 (2006), 36. 
how the learner acquires knowledge and to what extent he/she can use it to solve authentic problems.

In 2002, the FACED launched the bachelor course in Psychology, which adhered to this constructivist, holistic, and student-centered learning driving philosophy. Configuration of CBE within constructivist learning means considering the influential accrual of knowledge, learning preferences and styles, expectations, and assumptions brought by students to the learning opportunity. ${ }^{7}$ Adoption of CBE implies holistic learning, since knowledge application, as mediated by meta-cognition and self-evaluation, becomes the paramount process beyond sole possession of knowledge. ${ }^{8}$ Competences are holistic as they include knowing and understanding, knowing how to act, and knowing how to be. ${ }^{9}$ Hence, lecturers are challenged to promote student active engagement, imaginative inquiry, contemplation, authentic problem solving, control over learning, and thus accommodating students preferred ways of learning. ${ }^{10}$ Such personalization of learning experience is crucial for development of many skills needed in the workplace. ${ }^{11}$

In searching for wholeness within higher education systems, one finds predominance of practices that focus on left hemisphere intelligences such as verbal-linguistic and logical/mathematical,${ }^{12}$ while neglecting right hemisphere ones due to different factors. First, the western tradition values almost exclusively the rational and conceptual learning modes. ${ }^{13}$ Second, it is difficult to analyze and educate for non-rational processes.$^{14}$ Third, some educationalists assume that individuals with developed left hemisphere competences will be able to manage their emotions, intuitions, and interpersonal competences. ${ }^{15}$

7 John Biggs, "Enhancing Teaching through Constructive Alignment," Higher education 32, no. 3 (1996): 348.

${ }^{8}$ Kouwenhoven, "Designing for competence," 60.

9 Pablo Beneitone and Bartolome Edurne, "Global Generic Competences with Local Ownership: a Comparative Study from the Perspective of Graduates in Four Regions," Tuning Journal of Higher Education 1, no. 2 (2014): 306, http://dx.doi.org/10.18543/tjhe-1(2)2014pp303-334.

${ }_{10}$ Paul Ramsden, Learning to Teach in Higher Education (London: Routledge, 1992), 101.

${ }^{11}$ Ernie Barrington, "Teaching to Student Diversity in Higher Education: How Multiple Intelligence Theory Can Help," Teaching in Higher Education 9, no. 4 (2004): 428.

12 Barrington, "Teaching to Student Diversity," 423.

13 Marianne Van Woerkom, "Critical Reflection as a Rationalistic Ideal," Adult Education Quarterly 60, no. 4 (2010): 347.

${ }^{14}$ Fred A.J. Korthagen, "Two Modes of Reflection," Teacher and Teacher Education 9, no. 3 (1993): 320.

15 Denis Postle, "Putting the Heart Back Into Learning," in Using experience for learning, ed. David Boud, Ruth Cohen, and David Walker (Buckingham: Society for Research into Higher Education and Open University Press, 2003), 33-45. 
Consequently, they are not promoting all spectrum of learning styles (LS) or multiple intelligences (MI), despite that non-rational, right-hemisphere, processes play a key role in learning. For instance, gestalts activate immediate interpretation when diverse stimuli occur simultaneously. ${ }^{16}$ Besides, being associated to student interests and motivations, emotions catalyze the making meaning process. ${ }^{17}$

Considering the above-mentioned aspects, it is questioned to what extent the FACED bachelor course in Psychology does promote multiple intelligences as superimposed to holistic learning styles contributing to the development of competences. Answering this research question was deemed important since it could assist the development of course improvement proposals based on comparison between the intended curriculum and the curriculum as enacted. ${ }^{18}$

\section{Competence-based learning at the Faculty of Education}

As it was previously mentioned, the FACED at UEM was re-opened in 2001, adopting the Dutch tradition of CBE. The rationale for choosing CBE was the need to offer transparent relationship between university education and core or transferable skills, so that the student could be prepared, in a lifelong learning perspective, for citizenship and productive career. ${ }^{19}$ Literature presents diverse definitions of competence, depending on the author background or interests. Within such profusion of meanings, competence is essentially seen as useful in bridging the gap between education and job requirements. ${ }^{20}$ In one perspective, Kouvenhoven, Howie, and Plomp ${ }^{21}$ define it as "the interplay between knowledge, skills and attitude attributes and the meta-cognitive capacity to apply them at the right time when required. Competence is the totality of (core) competencies required to perform as a competent professional".

16 Korthagen, "Two Modes," 319.

17 Flávia M.T. Santos, "As Emoções nas Interacções e a Aprendizagem Significativa," Ensaio Pesquisa em Educação em Ciências 9, no. 2 (2007): 184.

18 van der Linden and Mendonça, "From Competence-Based," 41.

19 Arlene Gilpin and Wagenaar Robert, "Approaches to Teaching," in Tuning Educational Structures in Europe. Universities' Contribution to the Bologna Process. An Introduction, ed. Robert Wagenaar and Julia González (Bilbao and Groningen: University of Deusto Press, 2006), 92 .

20 Beneitone and Bartolomé, "Global Generic Competences," 305.

21 van der Linden \& Mendonça, "From Competence-Based," 38. 
Since 2014, the FACED has been involved in the Tuning initiative. Aiming to communicate with stakeholders, Tuning adopted the concept of competence, which is holistic as it aggregates knowledge, skills, and social attitudes and behaviours as related dimensions of competence..$^{22}$ Accordingly, Tuning defines competences as "dynamic combinations of cognitive and metacognitive skills, knowledge and understanding, interpersonal, intellectual and practical skills, and ethical values and they are developed in all course units and assessed at different stages of a programme." ${ }^{23}$

The definitions above present significant commonalities. First, they view competences as situational since they mean the aptitude to solve real problems. Second, in both definitions, competences comprise knowing and understanding, applying knowledge, knowing how to behave. ${ }^{24}$ Hence they are holistic since, in line with Lopez-Bonilla and Lopez-Bonilla, ${ }^{25}$ they view competences as integration of cognitive capabilities, cooperation, behavior and social interaction, feelings and emotions, generosity and sympathy, imagination, and sensitivity.

Constructivist and student-centred learning frame the promotion of CBE as it challenges students to make meaning by building on their prior knowledge and experience. Since it regards activity as the panacea for the learner to translate theory into practice, learning will essentially entail discussing, solving problems, and cooperating ${ }^{26}$ The bachelor in psychology adopts constructivist learning since it challenges students to make meaning through thinking critically, solving authentic problems, and engaging in groups, among others activities. Promotion of group engagement is recognizing that learning is concomitant to social interaction, since according to Vygotsky, ${ }^{27}$ the ways in which people acquire knowledge and interpret the world are determined by interactions they carry out within their social experiences. Such interaction has an instrumental role allowing the learner to grasp the meaning through explaining, elaborating and defending his/her

${ }^{22}$ Robert Wagenaar, "Competences and Learning Outcomes: A Panacea for Understanding the (new) Role of Higher Education?" Tuning Journal of Higher Education 1, no. 2 (2014): 289.

${ }^{23}$ Serbati, "Implementation of Competence-Based," 27.

${ }^{24}$ Beneitone and Bartolomé, "Global Generic Competences," 46.

25 Jesus M. López-Bonilla and López-Bonilla L. Miguel, "Holistic Competence Approach in Tourism Higher Education: An Exploratory Study in Spain," Current Issues in Tourism 17, no. 4 (2014): 316. DOI: 10.1080/13683500.2012.720248.

${ }^{26}$ Ramsden, Learning to teach, 101.

27 Jorge J. Fringe, "Promoting Critical Reflection for Academic Professional Development in Higher Education" (PhD diss., University of Pretoria, 2013), 50. 
position in discussion with colleagues. ${ }^{28}$ These processes require active search and analysis of information, as well as recognition that the other participants within this process might possess information that is either challenging or complementary to one's position. In turn, the promotion of solving authentic problems reminisce situated learning which views learning as an activity embedded in and animating practice, and practice as shaping learning. Central issue in learning is to become a practitioner learning from practice, rather than learning about practice. ${ }^{29}$ Meanwhile, the lecturer's role revolves around being motivator and witness, coach and facilitator, assessor, and remediator. ${ }^{30}$

CBE distinguishes generic/transversal from specific competences. While generic competences identify common attributes predictable to be developed by students of any degree, specific competences prepare the student for the profession. ${ }^{31}$ The FACED bachelor in Psychology generic competences was informed by stakeholders consultation. ${ }^{32}$ Therefore, ten (10) generic competences were defined, including communication, information management, leadership, project management, social interaction, reflection, ethics, design, and research and information technology.$^{33}$

\section{Holistic learning styles and multiple intelligences}

The holistic learning styles model, encapsulated within the whole-brain model ${ }^{34}$ was developed in reaction to educational practices that have for long focused on promoting left brain-related skills. Being innovative, intuitive, emotional and spiritual have been neglected in favour of analytical, rational, and logical processes. ${ }^{35}$ The whole brain model (see figure 1) conceives the

${ }^{28}$ Fringe, "Promoting Critical Reflection," 50.

${ }^{29}$ John S. Brown, Collins Allan and Duguid Paul, "Situated Cognition and the Culture of Learning," Educational Researcher 18, no. 1 (1989): 32-42.

${ }^{30}$ Linda L. Nussbaumer, "Theoretical Framework for Instruction that Accommodates all Learning Styles," Journal of interior design 27, no. 2 (2001):44.

${ }^{31}$ López-Bonilla and López-Bonilla, "Holistic Competence," 315.

32 van der Linden and Mendonca, "From Competence-Based," 38.

${ }^{33}$ Arlindo Sitoe et al., Currículo Ajustado de licenciatura em Psicologia (Maputo: UEM, 2012), 10-12.

${ }^{34}$ Ned Herrmann, The Creative Brain, $5^{\text {th }}$ ed. (North Carolina: The Ned Herrmann Group, 1995), 63.

${ }_{35}$ Ann-Louise De Boer and van den Berg Dorette, "The Value of the Herrmann Brain Dominance Instrument (HBDI) in Facilitating Effective Teaching and Learning of Criminology," Acta Criminologica 14, no. 1 (2001): 119. 
individual as a composite whole of needs, thoughts, values, feelings and actions. According to Herrmann, ${ }^{36}$ Sonnier and Sonnier, ${ }^{37}$ and Nussbaumer ${ }^{38}$ the model assumes brain dominance as natural and normal for all persons. It presents a metaphoric brain division into four quadrants representing distinct learning styles ${ }^{39}$ featured by:

- A quadrant favours analysing, figuring out, logical thinking and quantifying.

- B Quadrant favours planning, verbalizing, action, rules, and structure.

- C Quadrant are sensitive, emotional, empathetic, interpersonal, and musical.

- D Quadrant are creative, playful, spontaneous, holistic, and synthesizing.

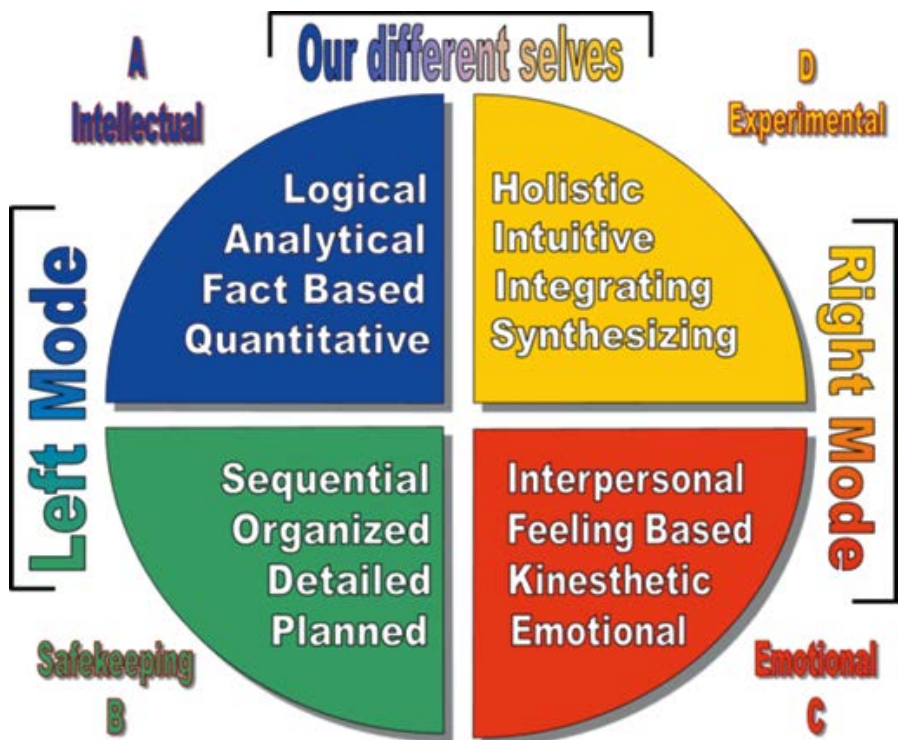

Figure 1

The whole-brain model (Fringe, 2013)

${ }^{36}$ Herrmann, The Creative Brain, 15-17.

37 Isadore L. Sonnier and Sonnier B. Claudine, "Nurturing Hemispheric Preference Through Affective Education," Journal of Instructional Psychology 22, no. 2 (1995): 182-185.

38 Nussbaumer, "Theoretical Framework for Instruction," 39-40.

${ }^{39}$ Herrmann, The Creative Brain, 79-85. 
Diverse reasons determine the adoption of Herrmann model. It is innovative, process-oriented, situation-focused, among the 13 most influential models and its instrument is one of the five more recommended instruments to education and training. ${ }^{40}$ It is comprehensive, ${ }^{41}$ including cognition, affectivity and doing. ${ }^{42}$ The model and its instrument, the Herrmann Brain Dominance Instrument has shown to aggregate criterion, face and construct validity. ${ }^{43}$ This model considers LS as passive to change, development, ${ }^{44}$ and regulation and development through parenting, life experiences, learning environment influences ${ }^{45}$ Moreover, the model aligns with constructivist and student centred learning, and promotes diversification and deep learning.

Gardner proposed the multiple intelligences (MI) theory pursuing to surpass previous biased IQ tests, which determined intelligence by testing individuals in artificial learning environments. Such tests do not assess the individual capacity to assimilate and solve daily, professional or personal problems ${ }^{46}$ Accordingly, Gardner advanced that intelligence is encouraged and displayed in the natural environment. ${ }^{47}$ Hence, it is more meaningful to devise it by challenging the individual to perform within such familiar environments.

Originally, Gardner has listed seven categories of intelligence namely the linguistic, logical-mathematical, spatial, bodily-kinesthetic, musical, interpersonal, and intrapersonal. ${ }^{48}$ For Gardner, all humans possess and have developed these intelligences in different degrees due to genetic and experiential

${ }^{40}$ Frank Coffield, Moseley David, Hall Elaine, and Ecclestone Kathrin, Learning Styles and Pedagogy in post-16 Learning: A Systematic and Critical Review (London: Learning and Skills Research Centre, 2004), 8-9.

${ }^{41}$ Ann-Louise De Boer, Du Toit Pieter H., Bothma Theo J. D., and Scheepers Detken, "Constructing a Comprehensive Learning Style Flexibility Model for the Innovation of an Information Literacy Module," Libri 62, no. 2 (2012), 185.

${ }_{42}$ Coffield, Moseley, Hall and Ecclestone, Learning Styles and Pedagogy, 83.

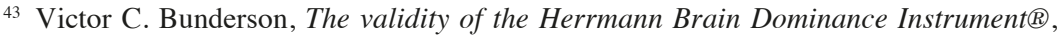
accessed July 25 2011, http://www.hbdi.com/uploads/100021_resources/100331.pdf.

${ }^{44}$ Ali K. A. Bawaneh, Abdullah G. K. Abdul, Saleh Salmiza, and Yin Y. Khoo, "Jordanian Students' Thinking Styles Based on Herrmann Whole Brain Model," International Journal of Humanities and Social Science 1, no. 9 (2011), 89.

${ }^{45}$ Herrmann, The Creative Brain, 19.

${ }^{46}$ Cláudia C.B Rego and Rocha N. M. Fraga, "Avaliando a Educação Emocional: Subsídios para um Repensar da Sala de Aula," Avaliação de políticas publicas em educação 17, no. 62 (2009), 142.

${ }^{47}$ Adrianna Kezar, "Theory of Multiple Intelligences: Implications for Higher Education," Innovative Higher Education 26, no. 2 (2001), 143.

${ }^{48}$ Ian J. McCoog, "Integrated Instruction: Multiple Intelligences and Technology," The Clearing House: A journal of Educational Strategies, Issues and ideas 81, no. 1 (2007), 25. 
factors. MI theory aligns the holistic concept of competence for which it is the totality of attributes (knowledge, skills and attitudes) required to perform as a competent professional. ${ }^{49}$ Hereafter educators are called to challenge the traditional notion of intelligence, mostly prevalent in Western societies, limited to linguistic and logical intelligences. Accordingly, they must nurture the varied human intelligences including the ability to see spatial patterns, to understand, relate and influence with other people, providing opportunities for learners to feel expert. ${ }^{50}$

This study adheres to the MI theory since it implies increased individualization of learning through independent study, experiential learning opportunities, self-paced learning, among others. The study recognises the MI potential to enhance conceptual understanding, positive attitudes toward learning, enjoyment and participation in learning, and create more authentic learning experiences ${ }^{51}$ Hence, it reckons constructivism, learner centredness, and situated learning as sign of appreciation of each learner's unique combination of intelligences.

The relevance of the MI theory draws further from its superimposition with the whole-brain model. Hence, the logical-mathematical intelligence is typical of the A quadrant; the verbal-linguistic occurs in both A and B quadrants; bodily-kinaesthetic, interpersonal, intrapersonal and musical intelligences are dominant in the C quadrant; and the visual-spatial is D quadrant.

In the same vein as the whole-brain model, the MI theory contends that each intelligence support certain learning activities. No intelligence or LS is functional in isolation. None is better than other. Each competence entails a complex mix of MI and LS involved..$^{52}$ Accordingly, the Tuning perspective contends that a person does not either possess or lack a competence in absolute terms, but commands it to a varying degree.$^{53}$ In considering the importance of cognition, affect and conation, this study adheres to both. It argues that differentiating methods of facilitating learning takes creativity and commitment. ${ }^{54}$

${ }^{49}$ Kouwenhoven, "Designing for Competence," 64.

${ }^{50}$ Kezar, "Theory of Multiple Intelligences," 143.

${ }^{51}$ Karen Goodnough, "Multiple Intelligences Theory: A Framework for Personalizing Science Curricula," School Science and Mathematics 101, no. 4 (2001), 181.

${ }^{52}$ Pieter H. Du Toit, "Matching Learning Style Flexibility and Action Research for Academic Staff Development" (paper presented at AERA Conference, New York, March 2428, 2008).

${ }^{53}$ Beneitone and Bartolomé, "Global Generic Competences," 46.

$54 \mathrm{McCoog}$, "Integrated Instruction,” 26. 
Learning Style Flexibility (LSF) ${ }^{55}$ rests on two assumptions. First, the learner is a whole person, with skills to plan and logically analyse facts, but who can also be emotionally involved, experiment, and integrate facts. A learner might have a preference for a certain quadrant (e.g. A) but no developed competence for a specific skill within such a quadrant (e.g. quantitative processing) because he/she missed the opportunity to develop such a skill. ${ }^{56}$ Hence there is a need to stimulate the learner's preference and challenge his/her avoidance.

Second, an entire group of learners considered predictably consists of a composite whole-brain. ${ }^{57}$ Hence lecturers have to adapt their style, following the holistic group composition, ${ }^{58}$ the nature of the subject matter and the intended learning outcomes. ${ }^{59}$ Otherwise, Felder ${ }^{60}$ indicates that the students' discomfort, associated with their way of learning being discriminated against, may hamper their full motivation to learn.

Lecturers should ideally design the tasks to move back and forth dynamically across all four quadrants, ensuring learning style flexibility ${ }^{61}$ As Sampaio indicates ${ }^{62}$ they must bear in mind that education cannot be restricted to acquisition of information or to logical and analytical thinking, since it must serve life, as well as human, social and environmental realization. Each key learning point must be tackled in ways representing different learning styles and multiple intelligences, including, for instance, a handout, a short video, a simulation, role playing, a team activity or a case study. ${ }^{63}$ That approach represents inclusive pedagogy which prevents students' marginalisation and allows them to use their strengths ${ }^{64}$ Hence lecturers will be espousing what students consider to be good teaching namely promoting students engagement at their level of understanding, showing respect for them, being flexible, and adopting methods that stimulate independent, active, and cooperative learning. ${ }^{65}$

55 De Boer, Du Toit, Bothma, and Scheepers, "Constructing a Comprehensive," 185.

${ }^{56}$ Herrmann, The Creative Brain, 76.

${ }^{57}$ Ned Herrmann, The Whole-Brain Business Book (New York: McGraw-Hill, 1996), 150.

${ }^{58}$ Du Toit, "Matching Learning Style," 28.

59 Serbati, "Implementation of Competence-Based," 21.

${ }^{60}$ Pieter H. Du Toit, De Boer Ann-Louise, and Steyn Tobias, "Learning Style Flexibility," in Facilitating Adult Learning: Reader, ed. Pieter H. Du Toit (Pretoria: University of Pretoria, 2006), 39 .

${ }^{61}$ De Boer, Du Toit, Bothma, and Scheepers, “Constructing a Comprehensive," 192.

${ }^{62}$ Rego and Rocha, "Avaliando a Educação," 143.

${ }^{63}$ Herrmann, The Whole-Brain, 153.

${ }^{64}$ Barrington, "Teaching to Student Diversity," 423.

${ }_{65}$ Ramsden, Learning to Teach, 89. 
The FACED bachelor in Psychology foresees the employment of tutorials, debates, workshops, simulations, seminars, field visits, projects, group work, audiovisual, and readings. ${ }^{66}$ Mixing this bachelor course proposed methods and the works of Herrmann ${ }^{67}$ and Gilpin and Wagenaar, ${ }^{68}$ a combination between methods of facilitating learning and the whole brain model was developed, as table 1 presents.

\section{Table 1}

Matching whole-brain and methods of facilitating learning

\begin{tabular}{|c|l|}
\hline Quadrant & \multicolumn{1}{|c|}{ Methods of facilitating learning } \\
\hline A & $\begin{array}{l}\text { Lecture, reading, self-paced instruction, problem based learning, } \\
\text { fact-based analysis, scheme development and tutorials. }\end{array}$ \\
\hline B & $\begin{array}{l}\text { Lecture, reading, individual projects, self-paced instruction, } \\
\text { problem based learning, individual projects, self-paced learning, } \\
\text { and tutorials. }\end{array}$ \\
\hline C & $\begin{array}{l}\text { Seminars, workshops, debates, cooperative learning, word games, } \\
\text { storytelling, field trips, case study, and drama/simulations. }\end{array}$ \\
\hline D & $\begin{array}{l}\text { Word games, brainstorming, storytelling, work based practice, } \\
\text { singing, visualisation, field trips, drama/simulations, and physical } \\
\text { involvement. }\end{array}$ \\
\hline
\end{tabular}

LSF acknowledges that learning is inextricably linked to the way a lecturer facilitates it. ${ }^{69}$ This linkage unfolds in a constructive alignment, ${ }^{70}$ which appeals for balance between methods of facilitating learning, students learning activities, and discipline knowledge. The FACED bachelor in Psychology, aims among others to develop students' competence to carry out psychosocial interventions on institutions and communities. In order to achieve that aim, students are for instance challenged to analyse, integrate and apply knowledge, cooperate in groups, and show commitment to ethical standards. Accordingly, lecturers have an array of methods such as lectures, debates, case study, brainstorming, field trips, and simulation. These methods denote the course designer's intension to promote holistic learning which

\footnotetext{
${ }^{66}$ Sitoe et al., Currículo Ajustado, 12.

${ }^{67}$ Herrmann, The Whole-Brain, 153.

${ }^{68}$ Gilpin and Wagenaar, "Approaches to Teaching," 94.

${ }^{69}$ Ramsden, Learning to Teach, 6.

70 Biggs, "Enhancing Teaching," 347.
} 
pursues to develop the learners functional, cognitive, social and behavioural competences. ${ }^{71}$

Holistic learning occurs when students are asked to search solutions for authentic, complex and ill-defined, problems emanating from professional practice. For that purpose, they have to select, interpret and apply relevant information. ${ }^{72}$ In this way, students will develop independence, selfawareness, self-control and understanding through intuition, imagination, contemplation, and visualization. ${ }^{73}$ The FACED bachelor in psychology aims to stimulate individual and collective responsibility through real life problem solving, contributing for development of students' ethics, spirit of responsibility, feelings attached learning, confidence, and resilience. ${ }^{74}$ Active problem solving fosters student interest, imaginative spirit, self-regulation, and recognises that students achieve higher through their preferred way of learning. ${ }^{75}$

\section{Research design and method}

This study intended to assess the extent to which FACED psychology lecturers accommodate MI as superimposed to holistic LS within their effort to develop the student competences. Being descriptive, the study concerned with depicting practical action. It sought to assess students' opinions and attitudes towards lecturing practice. ${ }^{76}$

In order to achieve the study objective, a questionnaire composed mostly by four-point Likert scale questions was developed. The rationale for the choice of questionnaire was the study nature as well as the instrument advantages, including easy administration, provision of direct responses, and greater honesty linked to anonymity. ${ }^{77}$

The questions composing the instrument resulted from collecting and collating significant items from different sources. For that purpose, there

71 Wagenaar, "Competences and Learning," 289.

72 Serbati, "Implementation of Competence-Based," 24.

73 Sheri R. Klein, "Holistic Reflection in Teacher Education: Issues and Strategies," Reflective Practice 9, no 2 (2008), 112.

${ }^{74}$ Rego and Rocha, “Avaliando a Educação,” 144.

75 Ramsden, Learning to Teach, 101.

${ }^{76}$ Antonio C. Gil, Métodos e Técnicas de Pesquisa Social, $6^{\mathrm{a}}$ ed. (São Paulo: Atlas, 2008), 28.

${ }^{77}$ Louis Cohen, Manion Lawrence, and Morrison Keith, Research Methods in Education, 5th ed. (London: Routledge Falmer, 2003), 101. 
was revision of the FACED Psychology study plan, multiple intelligences assessment instruments, and the Herrman Brain Dominance Instrument (HBDI), which has shown to aggregate criterion, face, and construct validity. ${ }^{78}$

The questionnaire comprised three main parts, namely respondents' characterisation, methods of facilitating learning, and students' activities related to MI and LS. In the two last parts, respondents were asked to indicate, through four-point Likert scale questions, the frequency with which lecturers adopted different methods of facilitating learning or promoted MI and LS-related activities. Respondents had to choose among four options, namely (1) never, (2) rarely, (3) frequently and (4) always. Then, from the least employed, they had to indicate which they would like to be more frequently adopted.

A stratified random sampling ${ }^{79}$ was adopted. In the first stage, the student population was stratified into four levels: first, second, third, and fourth year. Then, they were simply randomly sampled within the four strata. They were previously explained about the study objectives and benefits, questionnaire anonymity, data confidentiality, and were given freedom to decide participating or not.

The questionnaire was piloted to 18 early childhood education students from the same faculty. It allowed getting feedback and adhering to measures that contribute to increase validity and reliability such as using students familiar language, writing simple, clear and precise items, avoiding leading, loaded, double-barreled and double negatives. ${ }^{80}$

Data was analysed mainly through descriptive statistics performed in a MS-Excel spreadsheet that was configured in order to assist the computational operation. Data reduction started before data collection, since coding was built into questionnaire construction providing precoded answers.$^{81}$ For simplicity in interpretation, data was dichotomised. Hence, never and rarely were aggregated as negative, while frequently and always was considered as positive. Computing frequencies and percentages of responses within each category allowed visualising the regularity with which methods of facilitating learning and student learning activities are employed within the course.

78 Bunderson, The validity of the Herrmann Brain Dominance Instrument@, accessed July 25 2011, http://www.hbdi.com/uploads/100021_resources/100331.pdf.

${ }^{79}$ Cohen, Manion and Morrison, Research Methods, 101.

${ }^{80}$ Cohen, Manion and Morrison, Research Methods, 248-249.

${ }^{81}$ Cohen, Manion and Morrison, Research Methods, 265. 


\section{Results}

The study involved 158 bachelor students in Psychology (43 male and 114 female). It included 59 first year, 45 second year, 29 third year and 25 forth year students. Their ages range between 18 and 37 years. The mean age is 22,6 ( $\mathrm{SD}$ of 4.5 ).

Concerning the frequency with which lecturer adopt methods that stimulate different LS and MI, table 2 shows that the majority of respondents mention lectures $(89 \%)$, debates $(87 \%)$, oriented reading $(85 \%)$, seminars $(82 \%)$ and brainstorming $(72 \%)$ as those employed frequently or always. Debates and brainstorming stimulate interpersonal intelligence superimposed to the $\mathrm{C}$ quadrant, while lectures, oriented reading, and seminars stimulate verbal-linguistic intelligence superimposed by the $\mathrm{AB}$ quadrants.

Table 2

Lecturer adoption of different methods of facilitating learning

\begin{tabular}{|c|c|c|c|c|}
\hline \multirow{2}{*}{$\begin{array}{l}\text { Methods of facilitating } \\
\text { learning (quadrant) }\end{array}$} & \multirow[b]{2}{*}{ Intelligency } & \multicolumn{3}{|c|}{ Frequency (percentage) } \\
\hline & & $\begin{array}{l}\text { Rarely or } \\
\text { never }\end{array}$ & $\begin{array}{l}\text { Frequently } \\
\text { or always }\end{array}$ & Total \\
\hline Lectures (AB) & Verbal-linguistic & $17(11 \%)$ & $139(89 \%)$ & 156 \\
\hline Debates (C) & Interpersonal & $20(13 \%)$ & $134(87 \%)$ & 154 \\
\hline Field work (CD) & Bodily-kinesthetic & $124(80 \%)$ & $31(20 \%)$ & 155 \\
\hline Diagrams/charts (D) & Visual-spatial & $138(91 \%)$ & $13(9 \%)$ & 151 \\
\hline Problem solving $(A B)$ & Logical-Mathemat. & $68(45 \%)$ & $84(55 \%)$ & 152 \\
\hline Brainstorming (C) & Interpersonal & $42(27 \%)$ & $113(73 \%)$ & 155 \\
\hline Case study $(A B)$ & Logical-Mathemat. & $98(63 \%)$ & $58(37 \%)$ & 156 \\
\hline Experiential learning (CD) & Bodily-kinesthetic & $99(64 \%)$ & $55(36 \%)$ & 154 \\
\hline Oriented Reading ( $A B)$ & Verbal-linguistic & $23(15 \%)$ & $135(85 \%)$ & 158 \\
\hline Study visits (CD) & Bodily-kinesthetic & $134(88 \%)$ & $19(12 \%)$ & 153 \\
\hline Drama/Simulations (CD) & Bodily-kinesthetic & $139(89 \%)$ & $17(11 \%)$ & 156 \\
\hline Individual projects (C) & Intrapersonal & $89(57 \%)$ & $66(43 \%)$ & 155 \\
\hline Seminars $(A B)$ & Verbal-linguistic & $27(17 \%)$ & $130(83 \%)$ & 157 \\
\hline
\end{tabular}


Respondents mentioned that lecturers rarely or never use diagrams and charts (91\%), drama and simulations (89\%), study visits (87), field work (80\%), experiential learning (64\%), and case study (63\%). Except case study, which is left hemisphere, all of these methods are linked to the right hemisphere.

Comparison between different levels, as displayed in table 3, show consistent results. Accordingly, lectures are mentioned to be employed frequently or always by 52 first year students (88\%), 43 second year (96\%), 22 third year $(76 \%)$ and 22 fourth year $(88 \%)$. Debates are mentioned to be employed frequently or always by 51 first year (86\%), 36 second year (80\%), 28 third year (97\%) and 19 fourth year (76\%).

\section{Table 3}

Methods of facilitating learning adopted in different years

\begin{tabular}{|l|c|c|c|c|c|c|c|c|}
\hline \multirow{2}{*}{ Method } & \multicolumn{2}{|c|}{1 st year } & \multicolumn{2}{c|}{ 2nd year } & \multicolumn{2}{c|}{ 3rd year } & \multicolumn{2}{c|}{ 4th year } \\
\cline { 2 - 10 } & RN & FA & RN & FA & RN & FA & RN & FA \\
\hline Lectures & 5 & 52 & 2 & 43 & 7 & 22 & 3 & 22 \\
\hline Debates & 7 & 51 & 7 & 36 & 1 & 28 & 5 & 19 \\
\hline Field work & 56 & 2 & 39 & 6 & 12 & 15 & 17 & 8 \\
\hline Diagrams/charts & 50 & 7 & 41 & 3 & 25 & 1 & 22 & 2 \\
\hline Problem solving & 27 & 31 & 18 & 25 & 15 & 12 & 8 & 16 \\
\hline Brainstorming & 13 & 45 & 11 & 33 & 12 & 17 & 6 & 18 \\
\hline Case study & 46 & 13 & 26 & 18 & 17 & 11 & 9 & 16 \\
\hline Experiential learning & 43 & 13 & 22 & 23 & 19 & 9 & 15 & 10 \\
\hline Oriented Reading & 9 & 50 & 4 & 41 & 7 & 22 & 3 & 22 \\
\hline Study visits & 57 & 0 & 41 & 2 & 18 & 10 & 18 & 7 \\
\hline Drama/simulations & 59 & 0 & 40 & 5 & 20 & 7 & 20 & 5 \\
\hline Individual Projects & 38 & 20 & 32 & 12 & 7 & 21 & 12 & 13 \\
\hline Seminars & 18 & 41 & 1 & 43 & 4 & 25 & 4 & 21 \\
\hline
\end{tabular}

Legend: RN - rarely or never; FA - frequently or always.

On the reverse side, diagrams and charts are mentioned to be used rarely or never by 50 first year (85\%), 41 second year (91\%), 25 third year (86\%), and 22 fourth year (88\%). Drama and simulations are mentioned to be used 
rarely or never by 59 first year (100\%), 40 second year (89\%), 20 third year (74\%), and 20 fourth year $(80 \%)$.

Data in table 3 shows that all $1^{\text {st }}$ year students indicated that study visits and drama and simulations were rarely or never used. These methods are increasingly mentioned from $2^{\text {nd }}$ year onward: study visits are mentioned by 2 second year (4\%), 10 third year (34\%), and by 7 fourth year (28\%). In turn, drama and simulations are mentioned by 5 first year (11\%), by 7 third year (24\%), and by 5 fourth year (20\%). The same pattern is somehow presented on case studies and experiential learning. Case studies are mentioned to be employed frequently or always by 13 first years students (22\%), 18 second year (40\%), 11 third year (38\%), and 16 fourth year (64\%). Experiential learning is mentioned to be employed frequently or always by 13 first year students (22\%), 23 second year (51\%), 9 third year (31\%), and 10 fourth year (40\%). Overall, one finds that lectures, debates, brainstorming and oriented reading are used frequently or always with consistency thought the whole course.

From the list presented in table 2, respondents had to indicate five methods they would like to see employed more often. The results presented on table 4

Table 4

Student preferred methods of facilitating learning

\begin{tabular}{|l|c|}
\hline \multicolumn{1}{|c|}{ Methods of facilitating learning } & Frequency \\
\hline Study visits & 103 \\
\hline Field work & 89 \\
\hline Drama/simulations & 78 \\
\hline Case study & 76 \\
\hline Experiential learning & 62 \\
\hline Individual projects & 48 \\
\hline Problem based learning & 46 \\
\hline Diagrams/graphics & 44 \\
\hline Seminars & 26 \\
\hline Brainstorming & 11 \\
\hline Debates & 10 \\
\hline Lectures & 8 \\
\hline Oriented Reading & 3 \\
\hline
\end{tabular}


show that respondents would like to be more engaged in methods such as case study (logical-mathematical intelligence associated to AB quadrants), study visits, field work, drama and simulations, and experiential learning. All of these are bodily-kinesthetic intelligences superimposed to the $\mathrm{CD}$ quadrants.

Brainstorming and debates (all interpersonal), seminars, lectures, and oriented reading (all verbal-linguistic), are the least mentioned methods. Seminars, lectures, and oriented reading are the sole methods associated with the left hemisphere on table 4. This might hint that students are being satisfactorily stimulated for the use of the left hemisphere.

Regarding the frequency with which lecturers promote learning activities linked to the MI and LS, respondents had again to choose options varying from never to always, as table 5 show.

\section{Table 5}

Lecturers promotion of student learning activities

\begin{tabular}{|l|l|c|c|c|}
\hline \multirow{2}{*}{$\begin{array}{c}\text { Students learning activities } \\
\text { (quadrant) }\end{array}$} & \multicolumn{1}{|c|}{ Intelligency } & \multicolumn{2}{|c|}{ Frequency (percentage) } \\
\cline { 3 - 5 } & & $\begin{array}{c}\text { Rarely or } \\
\text { never }\end{array}$ & $\begin{array}{c}\text { Frequently } \\
\text { or always }\end{array}$ & Total \\
\hline Text prodution (AB) & Verbal-linguistic & $44(29 \%)$ & $110(71 \%)$ & 154 \\
\hline Cause-effect analysis (B) & Logical-Mathemat. & $91(61 \%)$ & $58(39 \%)$ & 149 \\
\hline Draw and photos (D) & Visual-spatial & $133(86 \%)$ & $21(14 \%)$ & 154 \\
\hline Interacting and sharing (C) & Interpersonal & $11(7 \%)$ & $145(93 \%)$ & 156 \\
\hline Ludic activities (D) & Interpersonal & $139(89 \%)$ & $18(11 \%)$ & 157 \\
\hline Listening to music (D) & Musical & $154(97 \%)$ & $4(3 \%)$ & 158 \\
\hline $\begin{array}{l}\text { Mathematical } \\
\text { operations (A) }\end{array}$ & Logical-Mathemat. & $112(72 \%)$ & $44(28 \%)$ & 156 \\
\hline $\begin{array}{l}\text { Work with graphs and } \\
\text { tables (D) }\end{array}$ & Visual-spatial & $132(84 \%)$ & $25(16 \%)$ & 157 \\
\hline Group work (C) & Interpersonal & $10(6 \%)$ & $147(94 \%)$ & 157 \\
\hline Drama/simulations (CD) & Bodily-kinesthetic & $136(87 \%)$ & $21(13 \%)$ & 157 \\
\hline $\begin{array}{l}\text { Developmen of self- } \\
\text { knowledge (C) }\end{array}$ & Intrapersonal & $60(38 \%)$ & $97(62 \%)$ & 157 \\
\hline $\begin{array}{l}\text { Activities envolving } \\
\text { singing (D) }\end{array}$ & Musical & $152(97 \%)$ & $5(3 \%)$ & 157 \\
\hline
\end{tabular}




\begin{tabular}{|c|c|c|c|c|}
\hline \multirow{2}{*}{$\begin{array}{l}\text { Students learning activities } \\
\text { (quadrant) }\end{array}$} & \multirow[b]{2}{*}{ Intelligency } & \multicolumn{3}{|c|}{ Frequency (percentage) } \\
\hline & & $\begin{array}{c}\text { Rarely or } \\
\text { never }\end{array}$ & $\begin{array}{l}\text { Frequently } \\
\text { or always }\end{array}$ & Total \\
\hline Oriented reading $(A B)$ & Verbal-linguistic & $14(9 \%)$ & $144(91 \%)$ & 158 \\
\hline $\begin{array}{l}\text { Responding to why } \\
\text { questions }(A)\end{array}$ & Logical-Mathemat. & $50(32 \%)$ & $106(68 \%)$ & 156 \\
\hline $\begin{array}{l}\text { Intuition based decision } \\
\text { making (D) }\end{array}$ & Intrapersonal & $127(81 \%)$ & $29(19 \%)$ & 156 \\
\hline Physical envolviment(D) & Bodily-kinesthetic & $138(88 \%)$ & $19(12 \%)$ & 157 \\
\hline Fact based analysis (A) & Logical-Mathemat. & $62(40 \%)$ & $93(60 \%)$ & 155 \\
\hline
\end{tabular}

Most respondents indicated that lecturers frequently or always promote group work $(94 \%)$, interacting and sharing ideas $(93 \%)$, oriented reading $(91 \%)$, text production $(71 \%)$, responding to why questions $(68 \%)$, development of self-knowledge (62\%), and fact-based analysis (60\%). On contrary, activities that involve music (97\%), ludic activities (89\%), physical involvement (88\%), drawing and photos $(86 \%)$, working with graphs and tables (84\%), intuition based decisions (81\%), and mathematical operations (72\%) were mentioned to be promoted rarely or never.

Looking for tendencies over different years, one finds worth remarking patterns, as table 6 shows. For instance, it is observed that text production is mentioned to be used frequently or always in a consistent fashion used across the all four years: 48 first year (78\%), 21 second year (47\%), 24 third year (83\%), and 19 fourth year (76\%). Interacting and sharing ideas with peers is mentioned by 55 first year (93\%), 41 second year (91\%), 25 third year (86\%), and 24 fourth year (96\%). Oriented Reading is mentioned to be employed frequently or always by 52 first year (88\%), 42 second year (93\%), 24 third year $(83 \%)$, and 23 fourth year (92\%).

Data also shows consistent pattern across the course years concerning the least stimulated learning activities. For instance, activities involving draw and photos are indicated to be promoted rarely or never by 49 first year students (83\%), 36 second year (80\%), 26 third year (90\%), and 22 fourth year $(88 \%)$. Ludic activities are mentioned to be promoted rarely or never by 52 first year students (88\%), 39 second year (87\%), 27 third year (93\%), and 21 fourth year $(94 \%)$. Work with graphs and tables is mentioned to be promoted rarely or never by 45 first year (76\%), 41 second year (91\%), 25 third year $(86 \%)$, and 21 fourth year $(84 \%)$. 
Table 6

Comparing learning activities adopted by year

\begin{tabular}{|l|c|c|c|c|c|c|c|c|}
\hline \multirow{2}{*}{ Learning activity } & \multicolumn{2}{|c|}{1 st year } & \multicolumn{2}{|c|}{ 2nd year } & \multicolumn{2}{|c|}{ 3rd year } & \multicolumn{2}{|c|}{ 4th year } \\
\cline { 2 - 10 } & RN & FA & RN & FA & RN & FA & RN & FA \\
\hline Text prodution & 13 & 46 & 21 & 21 & 5 & 24 & 5 & 19 \\
\hline Cause-effect analysis & 33 & 21 & 30 & 12 & 14 & 14 & 14 & 11 \\
\hline Draw and photos & 49 & 9 & 36 & 8 & 26 & 2 & 22 & 2 \\
\hline Interacting and sharing ideas & 3 & 55 & 3 & 41 & 4 & 25 & 1 & 24 \\
\hline Ludic activities & 52 & 7 & 39 & 6 & 27 & 1 & 21 & 4 \\
\hline Listening to music & 59 & 0 & 42 & 3 & 29 & 0 & 24 & 1 \\
\hline Mathematical operations & 29 & 30 & 38 & 5 & 26 & 3 & 19 & 6 \\
\hline Work with graphs and tables & 45 & 13 & 41 & 4 & 25 & 4 & 21 & 4 \\
\hline Group work & 2 & 56 & 3 & 42 & 2 & 27 & 3 & 22 \\
\hline Drama/simulations & 57 & 1 & 36 & 9 & 21 & 8 & 22 & 3 \\
\hline Development of self-knowledge & 24 & 35 & 12 & 32 & 16 & 13 & 8 & 17 \\
\hline Activities involving singing & 57 & 2 & 42 & 2 & 28 & 1 & 25 & 0 \\
\hline Oriented reading & 6 & 52 & 2 & 42 & 4 & 24 & 1 & 23 \\
\hline Responding to why questions & 19 & 39 & 10 & 35 & 12 & 16 & 9 & 16 \\
\hline Intuition based decision making & 50 & 8 & 38 & 6 & 27 & 2 & 12 & 13 \\
\hline Physical involviment & 52 & 7 & 41 & 4 & 25 & 4 & 20 & 4 \\
\hline Fact based analysis & 31 & 27 & 16 & 29 & 9 & 19 & 6 & 18 \\
\hline
\end{tabular}

Legend: RN - rarely or never; FA - frequently or always.

Concerning learning activities that respondents would like to see lectures promote more often, results, in table 7, show that ludic activities, activities involving music, drawings and photos, physical involvement, development of self-knowledge, and searching responses for why questions are the most mentioned. Almost all of these activities are related to $\mathrm{C}$ and D quadrants, except searching responses for why questions, which is located in A quadrant. 
Table 7

Students preferences for $\mathrm{MI}$ and LS related learning activities

\begin{tabular}{|l|l|c|}
\hline \multicolumn{1}{|c|}{ Learning activity (quadrant) } & \multicolumn{1}{c|}{ Intelligency } & Frequency \\
\hline Ludic activities (D) & Interpersonal & 53 \\
\hline Activities involving music (D) & Musical & 53 \\
\hline Draw and photos (D) & Visual-spatial & 35 \\
\hline Physical involviment (D) & Bodily-kinesthetic & 35 \\
\hline Development of self-knowledge (C) & Intrapersonal & 30 \\
\hline Work with graphs and tables (D) & Visual-spatial & 26 \\
\hline Responding why questions (A) & Logical-Mathemat & 20 \\
\hline Text production (AB) & Verbal-linguistic & 16 \\
\hline Mathematical operations (A) & Logical-Mathemat & 9 \\
\hline Fact-based analysis (A) & Logical-Mathemat & 6 \\
\hline Group work (C) & Interpersonal & 3 \\
\hline
\end{tabular}

\section{Discussion and conclusions}

According to the results presented above, the FACED bachelor of psychology lecturing promotes CBE through holistic learning and MI, despite the predominance of intelligences and learning styles linked to the left hemisphere. Lectures $(A B)$, debates $(C)$ oriented reading $(A B)$, brainstorming $(\mathrm{D})$, problem solving $(\mathrm{AB})$, and seminars $(\mathrm{AB})$ are mentioned to be employed frequently or always. From the MI perspective, these results portray a prevalence of promotion of verbal-linguistic, logical-mathematical and interpersonal intelligence. On the other side, diagrams and charts (D), drama and simulations (D), study visits (CD), field work (CD), experiential learning (D), and case study (C) are mentioned to be rarely or never used. Aligned to these results, scholars such as Korthagen, ${ }^{82}$ De Boer and Van den Berg ${ }^{83}$ and van Woerkom ${ }^{84}$ indicate that right hemisphere related skills and activities are the focus of reduced attention within teaching practice and

82 Korthagen, "Two Modes," 320.

83 De Boer and van den Berg, "The value of the Herrmann," 119.

84 Van Woerkom, "Critical Reflection," 345. 
research. That finding represents an additional challenge for lecturers to increase their effort towards promotion of holistic competences, which are related to what a person knows, does, and feels,${ }^{85}$ and require students to be actively dealing with content. Against overreliance on rationality, lecturers are defied to increase their efforts towards promoting learning connected to practical forms of questioning, facilitating emotion and intuition-based as well as implicit learning. ${ }^{86}$

Consistent with previous results, respondents mentioned that they would like to have more opportunities to engage with study visits, field work, drama and simulations, case study and experiential learning. Except case study (logical-mathematical), all these methods are linked with the bodily-kinesthetic intelligence. That demonstrates students' need for opportunities to intervene like experts within authentic learning environments where they can be physically involved and manipulate things, having their varied intelligences nurtured ${ }^{87}$ and arousing their interest and imaginative spirit. $^{88}$

Concerning the promotion of students learning activities linked to the MI and LS, the results show that debates $(\mathrm{C})$, group work (C), interacting and sharing ideas $(\mathrm{C})$, texts production $(\mathrm{AB})$, responding to why questions $(\mathrm{A})$ and development of self-knowledge $(\mathrm{C})$ are promoted frequently or always. On the other hand, activities that involve music (D), ludic activities (D), drama and simulations (D), drawing and photos (D), physical involvement (D), and intuition-based decisions (D), working with graphs and tables (D), and mathematical operations (A) are rarely or never promoted. Respondents indicate the need to be more exposed to ludic activities, activities involving music, drawings and photos, and physical involvement.

Overall, the results show that within the FACED Bachelor in Psychology there is a tiny accommodation of the whole spectrum of LS and MI. Still these results display a way to go to increase the promotion of the right hemisphere-related MI and LS. The current study acknowledges that learning entails students developing skills to quantify, to logically analyse facts, to structure and organise things. But it also defends the need to promote active engagement, team work, problem solving, and hands-on learning; since education entails life, social and environmental realisation. ${ }^{89}$ This context challenges lecturers to increase efforts for promotion of meaningful learning,

\footnotetext{
${ }^{85}$ López-Bonilla and López-Bonilla, "Holistic Competence,” 316.

${ }^{86}$ Van Woerkom, "Critical Reflection," 345.

${ }^{87}$ Kezar, "Theory of Multiple Intelligences," 143.

${ }^{88}$ Ramsden, Learning to Teach, 101.

${ }^{89}$ Rego and Rocha, “Avaliando a Educação," 143.
} 
stimulating authentic and affective learning experiences. ${ }^{90}$ Such efforts to develop holistic competences are maximised by opportunities for students' active involvement, self-regulation and, consequently, intrinsic motivation..$^{91}$

Although it is beyond the scope of the current study to advance with concrete proposals, it is apparent that the promotion of lecturers' professional development would be one step towards the mentioned increased promotion of competences through facilitating holistic learning strategies. An array of possible approaches ranging from informal, through non-formal to formal ones can be considered. Hence, short-courses, workshops, mentoring, roundtables discussions could be adopted. All of these should be practice and problem-focused and reflective practice-oriented.$^{2}$ Beyond that proposition, literature is plenty of exemplars of how that could be done, especially in this new era that requires balance of local and international dimensions, new and more demanding students with the same teaching resources,${ }^{93}$ and featured by the extension of the traditional roles of lecturers who, among others, have to be managers and extensionists, course designers, marketers and technology experts, scholars, researchers and lifelong learners, and discipline specialists.

\section{Bibliography}

Armstrong, Thomas. Multiple intelligences in the classroom. Alexandria: Association for Supervision and Curriculum Development, 1994.

Barrington, Ernie. "Teaching to Student Diversity in Higher Education: how Multiple Intelligence Theory can help." Teaching in Higher Education 9, no. 4 (2004): 421-434.

Bawaneh, Ali K. Ali, Abdullah Abdul G. Kanesan, Saleh Salmiza, and Yin K.Yin. "Jordanian Students' Thinking Styles based on Herrmann Whole Brain Model". International Journal of Humanities and Social Science 1, no. 9 (2011): 89-97.

Beneitone, Pablo, and Bartolome Edurne. "Global Generic Competences with Local Ownership: A Comparative Study from the Perspective of Graduates in Four Regions." Tuning Journal of Higher Education 1, no. 2 (2010): 303-334. http:// dx.doi.org/10.18543/tjhe-1(2)-2014pp303-334.

Biggs, John. "Enhancing Teaching through Constructive Alignment." Higher education 32, no. 3 (1996): 347-364.

Brown, John S., Collins Allan, and Duguid Paul. Situated Cognition and the Culture of Learning, Educational Researcher 18, no. 1 (1989): 32-42.

\footnotetext{
90 Santos, “As emoções nas Interacções," 174.

91 Serbati, "Implementation of competence-based," 24.

92 Fringe, "Promoting critical reflection," 48.

93 Serbati, "Implementation of competence-based," 52.
} 
Bunderson, Victor C. The validity of the Herrmann Brain Dominance Instrument $B$, 1985. Accessed July 25 2011, http://www.hbdi.com/uploads/100021_ resources/100331.pdf.

Coffield, Frank, Moseley David, Hall Elaine, and Ecclestone Kathrin. Learning styles and Pedagogy in post-16 Learning: A systematic and Critical Review. London: Learning and Skills Research Centre, 2004.

Cohen, Louis, Manion Lawrence, and Morrison Keith. Research Methods in Education. London: Routledge Falmer, 2003.

Dart, Barry. "Adult Learner's Metacognitive Behaviour in Higher Education" In Adult Learning: A Reader, edited by Peter Sutherland, 30-43. London: Kogan Page, 1997.

De Boer, Ann-Louise, and van den Berg Dorette. "The value of the Herrmann Brain Dominance Instrument (HBDI) in Facilitating Effective Teaching and Learning of Criminology." Acta Criminologica 14, no. 1 (2001):119-129.

De Boer, Ann-Louise, Du Toit Pieter H., Bothma Theo J. D., and Scheepers Detken. "Constructing a Comprehensive Learning Style Flexibility Model for the Innovation of an Information Literacy Module." Libri 62, no. 2 (2012): 185-196.

Du Toit, Pieter H. "Matching Learning Style Flexibility and Action Research for Academic Staff Development." Paper presented at AERA Conference. New York, March 24-28, 2008.

Du Toit, Pieter H., De Boer Ann-Louise and Steyn Tobias. "Learning Style Flexibility." In Facilitating Adult Learning: Reader, edited by Pieter H. Du Toit, 35-49. Pretoria: University of Pretoria, 2006.

Fringe, Jorge J. "Promoting Critical Reflection for Academic Professional Development in Higher Education.” PhD diss., University of Pretoria, 2013.

Gil, Antonio C. Métodos e Técnicas de Pesquisa Social. 6a edição. São Paulo: Atlas, 2008.

Gilpin, Arlene, and Wagenaar Robert. "Approaches to Teaching, Learning and Assessment in Competence Based Degree Programmes." In Tuning Educational Structures in Europe. Universities' Contribution to the Bologna Process. An Introduction, edited by Robert Wagenaar \& Julia González, 91-118. Bilbao and Groningen: University of Deusto Press, 2006.

Goodnough, Karen. "Multiple Intelligences Theory: A Framework for Personalizing Science Curricula." School Science and Mathematics 101, no. 4 (2001): 180-193.

Herrmann, Ned. The Creative Brain. $5^{\text {th }}$ ed. North Carolina: The Ned Herrmann Group, 1995.

Herrmann, Ned. The Whole-Brain Business Book. New York: McGraw-Hill, 1996.

Kezar, Adrianna. "Theory of Multiple Intelligences: Implications for Higher Education.” Innovative Higher Education 26, no. 2 (2001): 141-154.

Korthagen, Fred A.J. "Two Modes of Reflection.” Teacher and Teacher Education 9, no. 3 (1993): 317-326.

Kouwenhoven, Wim G. "Designing for Competence: Towards a Competence-Based Curriculum for the Faculty of Education of the Eduardo Mondlane University." PhD diss., University of Twente, 2003. 
Linden, Johanna van der, and Mendonca Marta. "From Competence-Based Teaching to Competence-Based Learning: The case of Generic Competencies in the Faculty of Education at the Eduardo Mondlane University in Mozambique." Perspectives in Education 24, no. 3 (2006): 37-51.

López-Bonilla, Jesus M., and López-Bonilla Luis M. "Holistic Competence approach in Tourism Higher Education: An Exploratory Study in Spain." Current Issues in Tourism 17, no. 4 (2014): 312-326. DOI: 10.1080/13683500.2012.720248.

McCoog, Ian J. "Integrated instruction: Multiple Intelligences and Technology." The Clearing House: A Journal of Educational Strategies, Issues and ideas 81, no. 1 (2007): 25-28.

Ministerio da Educacao. Plano Estratégico do Ensino Superior 2012-2020 [20122020 Strategic plan of higher education]. Moçambique, 2012.

Ministry of Higher Education, Science and Technology. Strategic Plan of Higher Education in Mozambique 200-2010. Mozambique, 2000.

Nussbaumer, Linda L. "Theoretical Framework for Instruction that Accommodates all Learning Styles.” Journal of Interior Design 27, no. 2 (2001): 35-45.

Pires, Maria R.G.M, Guilhem Dirce, and Gottems Leila B.D. "The (in)dica-sus Game: A Strategy of Game-Based Learning of the Unified Health System." Text context nursing 22, no. 2 (2013): 379-388.

Postle, Denis. "Putting the Heart Back Into Learning." In Using Experience for Learning, edited by Boud, David, Cohen, Ruth and Walker, David, 33-45. Buckingham: Society for Research into Higher Education \& Open University Press, 2003.

Ramsden, Paul. Learning to Teach in Higher Education. London: Routledge, 1992.

Rego, Cláudia C.B, and Rocha N. M. Fraga. Avaliando a Educação Emocional: Subsídios para um Repensar da Sala de Aula. Avaliação de políticas publicas em educação 17, no. 62 (2009): 135-152.

Santos, Flávia M.T. "As emoções nas Interacções e a Aprendizagem Significativa.” Ensaio Pesquisa em Educação em Ciências 9, no. 2 (2007):173-187.

Serbati, Anna. "Implementation of Competence-Based Approach: Stories of Practices and the Tuning Contribution to Academic Innovation." Tuning Journal of Higher Education 3, no. 1 (2015): 19-56. 10.18543/tjhe-3(1)-2015pp19-56.

Sheri R. Klein, "Holistic Reflection in Teacher Education: Issues and Strategies", Reflective Practice 9, no 2 (2008), 111-121.

Sitoe, Arlindo et al. Currículo Ajustado de Licenciatura em Psicologia. [Adjusted Bachelor in Psychology Curriculum]. Maputo: UEM, 2012.

Sonnier, Isadore L., and Sonnier Claudine B. "Nurturing Hemispheric Preference Through Affective Education." Journal of Instructional Psychology 22, no. 2 (1995): 182-185.

Van Woerkom, Marianne. "Critical Reflection as a Rationalistic Ideal." Adult Education Quarterly 60, no. 4 (2010): 339-356. DOI: 10.1177/0741713609358446.

Wagenaar, Robert. "Competences and Learning Outcomes: A Panacea for Understanding the (new) Role of Higher Education?" Tuning Journal of Higher Education 1, no. 2 (2014): 279-302. 


\section{About the author}

JORGE JAIME DOS SANTOS FRINGE (jorge.fringe@gmail.com/jorge.fringe@ uem.mz) is lecturer at the Department of Psychology, Faculty of Education of the University Eduardo Mondlane, Mozambique. He holds a Bachelor of Psychology and Pedagogy, a Masters in Sciences of Education, and a PhD in Education. Jorge Fringe has about 17 years' experience in Teaching, Research and Management, having been among others head of Department, Deputy-Dean for Graduate Studies and Acting Dean of the Faculty. Presently he is serving the Conselho Nacional de Avaliacao de Qualidade (National Council for Evaluation and Quality Assurance), as Director for Promotion of the SINAQES (National System for Quality Assurance). His research interest areas include learning styles, critical reflection, professional development, and action research. 


\title{
Promoting holistic learning for the development of competences in Mozambique
}

\author{
Jorge Jaime dos Santos Fringe
}

doi: http://dx.doi.org/10.18543/tjhe-5(2)-2018pp19-43

Received: 22.01 .2018

Accepted: 02.05.2018

\section{Copyright}

Copyright for this article is retained by the Publisher. It is an Open Access material that is free for full online access, download, storage, distribution, and or reuse in any medium only for noncommercial purposes and in compliance with any applicable copyright legislation, without prior permission from the Publisher or the author(s). In any case, proper acknowledgement of the original publication source must be made and any changes to the original work must be indicated clearly and in a manner that does not suggest the author's and or Publisher's endorsement whatsoever. Any other use of its content in any medium or format, now known or developed in the future, requires prior written permission of the copyright holder. 